\title{
Article \\ Effect of Initial Planting Density on Growth Traits and Wood Properties of Triploid Chinese White Poplar (Populus tometosa) Plantation
}

\author{
Yaru Sang 1,2,3 , Peng Gao ${ }^{1,2,3}$, Xiangyang Kang ${ }^{1,2,3}$ and Pingdong Zhang 1,2,3,*(D) \\ 1 College of Biological Sciences and Technology, Beijing Forestry University, Beijing 100083, China; \\ sangyaru128922@163.com (Y.S.); gaogaopengpeng@163.com (P.G.); kangxy@bjfu.edu.cn (X.K.) \\ 2 National Engineering Laboratory for Tree Breeding, Beijing Forestry University, Beijing 100083, China \\ 3 Key Laboratory of Genetics and Breeding in Forest Trees and Ornamental Plants, Ministry of Education, \\ Beijing Forestry University, Beijing 100083, China \\ * Correspondence: zhangpd@bjfu.edu.cn
}

check for

updates

Citation: Sang, Y.; Gao, P.; Kang, X.; Zhang, P. Effect of Initial Planting Density on Growth Traits and Wood Properties of Triploid Chinese White Poplar (Populus tometosa) Plantation. Forests 2021, 12, 1676. https://doi. org/10.3390/f12121676

Received: 28 September 2021

Accepted: 28 November 2021

Published: 30 November 2021

Publisher's Note: MDPI stays neutral with regard to jurisdictional claims in published maps and institutional affiliations.

Copyright: (c) 2021 by the authors. Licensee MDPI, Basel, Switzerland. This article is an open access article distributed under the terms and conditions of the Creative Commons Attribution (CC BY) license (https:// creativecommons.org/licenses/by/ $4.0 /)$.

\begin{abstract}
Planting density primarily affects the yield and wood quality of plantations. There are multiple reports on the effects of planting density on growth traits and wood properties in young triploid Chinese white poplar (Populus tomentosa) plantations. Nevertheless, assessment of the effects of initial planting density is lacking for plantations older than ten years. Here, an 11-year-old plant density trial $\left(2490,1665,1110,832,624,499\right.$, and 416 trees $\left./ \mathrm{hm}^{2}\right)$ established with four hybrid clones (S86, B301, B331 and 1316) in northern China was used to determine the effect of initial planting density on growth traits (diameter at breast height (DBH), tree height $(\mathrm{H})$, stem volume (SV) and stand wood volume (SWV)), basic wood density (BWD), and fiber properties (fiber length (FL), fiber width (FW), and the ratio of fiber length to width (FL/FW)). A total of 84 trees from four clones were sampled. In this study, the initial planting density had a highly significant effect on growth traits $(p<0.001)$ and had a moderate effect on FL. Overall, the reduction in initial planting density led to the increase in DBH, H, SV, and FL/FW. Triploid hybrid clones planted at 416 trees $/ \mathrm{hm}^{2}$ had the largest DBH, H, SV, FL/FW and the smallest SWV and FW. Clonal effects were also significant $(p<0.05)$ for all studied traits except for FL. Clone S86 had a higher growth rate and the largest BWD and FW. Clones-initial planting densities interaction was insignificant for all growth traits and wood properties. A weak and positive estimated correlation between BWD and growth traits $(\mathrm{H}, \mathrm{SV}, \mathrm{SWV})$ within each planting density was seen. Our results demonstrate that an appropriate reduction in initial density in triploid Chinese white poplar plantations with long rotation is a suitable strategy to promote tree growth and retain excellent wood processing characteristics.
\end{abstract}

Keywords: initial planting density; Populus tomentosa; growth traits; basic wood density; fiber properties; triploid hybrid clones

\section{Introduction}

Planting density is an important cultivation factor for stand wood production. It affects the survival rate, tree growth, wood quality, wood yield, and biodiversity of plantation [1,2]. For example, there is a negative correlation between planting density and stem volume (SV). At low planting densities, the individual tree volume growth increases [3,4]. According to Johnstone's findings [5], the initial planting density positively affects the mean diameter of hybrid poplars. In terms of 9 -year mean diameter, the trees with the widest spacing $(4.5 \mathrm{~m} \times 4.5 \mathrm{~m})$ were about twice as large as those with the closest spacing $(1.5 \mathrm{~m} \times 1.5 \mathrm{~m})$. There was a strong influence of planting density on hybrid poplar trees individual stem dimensions or volume after 8 and 14 years in southern Quebec, Canada [6]. Liziniewicz et al. [7] recorded that the mean height of 23-year-old lodgepole pine increased with increasing initial planting density. The initial planting density also 
affects wood properties, such as basic wood density (BWD) [8-10], fiber traits [10], and wood chemical composition [11]. Ahmed et al. [12] reported that the planting density influence on growth traits and wood properties is greater than that of the wood chemical composition. Research on guapuruvu [13] showed that planting density only significantly affected the fiber length (FL) and fiber wall thickness. Therefore, the initial planting density choice is crucial to maximize growth rate and optimize wood quality.

Chinese white poplar (Populus tomentosa) is a fast-growing native tree species in China. A natural triploid $(2 n=3 x=57)$ Chinese white poplar was first discovered by Zhu [14] in 1992, and it was believed to be the product of hybridization between normal (1n) egg cells and natural $(2 \mathrm{n})$ pollen. Combined with the heterosis and ploidy of its parents, the triploid hybrid clones exhibit outstanding growth, fiber traits, and stress resistance. Higher growth rate, longer fibers, higher cellulose and holocellulose content, and lower lignin content characterize the triploid hybrid clones of Chinese white poplar $[14,15]$. The superior growth traits and wood properties of triploid hybrid clones make them become the preferred species in the pulp and paper industries and the sawn timber industry. As a high-yield fiber source, triploid hybrid clones are widely cultivated in northern China, especially in Shandong, Shanxi, Henan, Hebei, and other provinces.

Previous studies documented the influence of initial planting density on growth traits and wood properties of triploid hybrid clones of Chinese white poplar. For example, Wang et al. [16] reported that the initial planting density significantly affected diameter at breast height $(\mathrm{DBH})$ and SV in a 4-year-old triploid Chinese white poplar plantation. The effects of initial planting density were significant for the $\mathrm{DBH}$, tree height $(\mathrm{H}), \mathrm{SV}$, and BWD of a 3 -year-old triploid Chinese white poplar plantation [17-19]. However, the initial planting densities and clone-initial planting density interactions had no significant effects on fiber properties or wood chemical components $[18,19]$. Triploid white poplar root distribution characteristics, root biomass, and its effect on water and soil nutrients under the wide-andnarrow spacing scheme were studied by Xi et al. [20] and Di et al. [21]. Additionally, the initial planting density was found to affect the root distribution of triploid Chinese white poplar significantly. Bo et al. [22] used a 9-year Chinese white poplar plantation in the North China Plain as material to evaluate the effect of planting density on growth traits. Their results show that planting density had significant effects on average tree $\mathrm{H}, \mathrm{DBH}, \mathrm{SV}$, and stand wood volume (SWV).

Stand growth was not only affected by initial planting density, but also stand age [23]. Although a range number of studies about the effect of initial planting density on growth traits and wood properties have been performed on plantations less than six years old, no data are available on the effects of initial planting density on the growth traits and wood properties of triploid Chinese white poplar when the plantation is older than ten years. In this study, we examined the wood properties and growth traits of three triploid hybrid clones and one diploid hybrid clone in an 11-year-old Chinese white poplar plantation with seven initial planting densities. The objectives of this study were to: (1) evaluate the effect of initial planting density on growth traits and wood properties, (2) determine clonal effects and the initial planting densities-clones interactions on growth traits and wood properties, and (3) examine the relationships between growth traits and wood properties within initial planting density. Our findings provide new insights into the management of Chinese white poplar plantations.

\section{Materials and Methods}

\subsection{Materials and Description of the Study Site}

The study was conducted in the Huayang Forest Tree Nursery, located in the Huabei Great Plain $\left(36^{\circ} 50^{\prime}-37^{\circ} 47^{\prime} \mathrm{N}, 113^{\circ} 52^{\prime}-115^{\circ} 49^{\prime} \mathrm{E}\right)$, a flat, alluvial region that experiences warm-temperate, continental, and semi-arid monsoon climate zones. During the year, the average temperature in January is the lowest at $-2.5^{\circ} \mathrm{C}$, while the average temperature in July is the highest at $27^{\circ} \mathrm{C}$. The annual total sunshine hours are about $2575 \mathrm{~h}$ with 
approximately 198 frost-free days. These meteorological conditions come from 50 years (1960-2010) of data from Wei county meteorological stations.

The materials used in this study were taken from an 11-year-old planting density trial established by the Beijing Forestry University at Wei County, Hebei Province, China. In this experiment, seven initial planting densities, $2 \mathrm{~m} \times 2 \mathrm{~m}\left(2490\right.$ trees $\left./ \mathrm{hm}^{2}\right)$, $2 \mathrm{~m} \times 3 \mathrm{~m}\left(1665\right.$ trees $\left./ \mathrm{hm}^{2}\right), 3 \mathrm{~m} \times 3 \mathrm{~m}\left(1110\right.$ trees $\left./ \mathrm{hm}^{2}\right), 3 \mathrm{~m} \times 4 \mathrm{~m}\left(832\right.$ trees $\left./ \mathrm{hm}^{2}\right)$, $4 \mathrm{~m} \times 4 \mathrm{~m}\left(624\right.$ trees $\left./ \mathrm{hm}^{2}\right), 4 \mathrm{~m} \times 5 \mathrm{~m}\left(499\right.$ trees $\left./ \mathrm{hm}^{2}\right)$, and $4 \mathrm{~m} \times 6 \mathrm{~m}\left(416\right.$ trees $\left./ \mathrm{hm}^{2}\right)$ with four hybrid clones (S86, B331, B301, and 1316) were used. The trials consisted of three triploid hybrid clones and one diploid clone in each planting density (Table 1). Clone S86, B331, and B301 were triploid with superior traits. The diploid clone 1316 was a superior tree of Chinese white poplar with a higher growth rate in northern China. Under the premise of the same management level, the experiment was established in a two-factor complete randomized block design. Seven planting densities were set up with three replicates and a total of 21 plots. Guard rows were planted around the entire perimeter to reduce edge effects. On each initial planting density, trees were sampled randomly in this study. A total of 84 trees from 4 clones were sampled to assess the effects of initial planting density on growth traits and wood properties of triploid Chinese white poplar. Thinning and fertilization were not carried out during the experiment.

Table 1. Identity and origin of the hybrid clones.

\begin{tabular}{ccccc}
\hline No. & Clone Identity & Parents & Level of Ploidy & Sex \\
\hline 1 & B301 & $(P$. tomentosa $\times$ P. bolleana $) \times$ P. tomentosa & Triploid & female \\
2 & B331 & $($ P. alba $\times$ P. glandulosa $) \times$. tomentosa & Triploid & female \\
3 & S86 & $($ P. tomentosa $\times$ P. bolleana $) \times(P$. alba $\times$ P. glandulosa $)$ & Triploid & male \\
4 & 1316 & P. tomentosa $\times$ P. tomentosa & Diploid & male \\
\hline
\end{tabular}

\subsection{Measurement of Tree Growth and Evaluation of Fiber Properties}

In the winter of 2018, the poplar improvement program of Beijing Forestry University measured the total $\mathrm{H}$ and $\mathrm{DBH}$ of 11-year-old trees. The DBH and $\mathrm{H}$ of each selected tree were measured using a laser vertex and DBH meter tap, respectively. Calculate the SV of each sample according to the volume function used by Chen [24] (Equation (1)):

$$
\mathrm{SV}=0.51340 \mathrm{H}^{0.826956} \mathrm{D}^{1.995375}
$$

where $\mathrm{SV}$ is stem volume, $\mathrm{H}$ is tree height, and $\mathrm{D}$ is diameter.

The SWV was calculated using the following equation (Equation (2)):

$$
\mathrm{SWV}=\mathrm{SV} \times \mathrm{N}
$$

where SWV is the stand wood volume in $\mathrm{m}^{3} / \mathrm{hm}^{2}, \mathrm{SV}$ is the mean stem volume of each plot in each replicate in $\mathrm{m}^{3}$, and $\mathrm{N}$ is the number of survival trees per square kilometer.

For determining the influence of initial planting density on BWD and fiber traits, a sample tree was randomly selected from each plot, and the total of sampled trees was 84 . A 10-cm-thick disk was taken from each sampled tree at breast height. A small rectangular pith-to-bark wood specimen with dimensions of $20 \mathrm{~mm}$ vertically $\times 20 \mathrm{~mm}$ radially was cut from the disk. The weight in air of the saturated wood sample and the oven dry weight of the same sample were determined to obtain the BWD of poplar by Smith's [25] maximum moisture content method.

To measure fiber properties, matchstick-sized wood samples were cut from the stem disk and macerated in a boiling 1:1 $(v / v)$ mixture of acetic acid and hydrogen peroxide. After that, an L\&W Fiber Tester was used to measure the FL and fiber width (FW) of each sample according to the method described in detail by Zhang et al. [26]. L\&W Fiber Tester is based on image analysis. It can measure 50,000 of fibers on each sample in a few minutes. The ratio of fiber length to width (FL/FW) was calculated based on FL and FW measured for each sample. 


\subsection{Statistical Analysis}

In this study, the diploid clone (1316) was excluded in the main statistical analysis. Therefore, only three triploid hybrids clones were involved in the main analyses of variance and correlation analysis. Analyses of variance were conducted using the UNIVARIATE procedure of the SPSS software (SPSS for Windows, version 20, SPSS, Chicago, IL, USA). Excel software was used to assist statistical analysis and drawing.

Variation among ramets of the sample clones was analyzed by analysis of variance, using a linear model (Equation (3)) within initial planting density:

$$
X_{j k}=\mu+C_{j}+\varepsilon_{j k} .
$$

where $X_{j k}$ is an observation on the $k$ th ramet from the $j$ th clone, $\mu$ is the general mean, $C_{j}$ is the effect due to the $i$ th clone, and $\varepsilon_{j k}$ is a random error. In the linear model (Equation (3)), the clone-replicate effects were not considered because the three trees per clone were chosen randomly.

The linear model (Equation (4)) was used for joint analyses of the seven initial planting densities together:

$$
Y_{i j k l}=\mu+B_{i}+C_{j}+S_{k}+C_{j} S_{k}+\varepsilon_{i j k l}
$$

where $Y_{i j k}$ is an observation on the $l$ th tree from the $j$ th clone in the $k$ th planting density at $i$ th block, $\mu$ is the overall mean, $B_{i}$ is the effect due to the $i$ th block, $C_{j}$ is the effect due to the $i$ th clone, $S_{k}$ is the effect due to the $k$ th spacing, $C_{j} S_{k}$ is the interaction between the $j$ th clone and $k$ th planting density, and $\varepsilon_{i j k}$ is random error. All terms were considered random, except for block, which was considered as a fixed effect.

The phenotypic correlations of clonal means for each pair of traits within initial planting density were calculated and tested for significance according to SPSS PROC CORR software.

\section{Results}

\subsection{Effect of Initial Planting Density on Growth Traits of Triploid Chinese White Poplar}

The mean values, range of variation, and coefficients of phenotypic variation for the studied growth traits of the seven planting densities are presented in Table 2. Among the initial planting densities, the studied growth traits of triploid Chinese white poplar trees were significantly better than those of diploid clone 1316. Overall, the $\mathrm{DBH}, \mathrm{H}$, and SV of triploid Chinese white poplar decreased with the increase in initial planting density. For triploid hybrid clones, the trees planted at 416 trees $/ \mathrm{hm}^{2}$ had the largest $\mathrm{DBH}, \mathrm{H}$, and SV. The lowest DBH, H, and SV were found for 2490 trees $/ \mathrm{hm}^{2}$. The DBH, $\mathrm{H}$, and SV differences between the lowest and highest means were $40.59 \%, 23.80 \%$, and $135.81 \%$, respectively. Clearly, growth was fastest for those planted at 416 trees $/ \mathrm{hm}^{2}$ and slowest for those planted at 2490 trees $/ \mathrm{hm}^{2}$. Among the seven initial planting densities, the SWV of triploid white poplar ranged from $145.0037 \mathrm{~m}^{3} / \mathrm{hm}^{2}$ to $372.4605 \mathrm{~m}^{3} / \mathrm{hm}^{2}$ after 11 years, with an average of $238.0123 \mathrm{~m}^{3} / \mathrm{hm}^{2}$. The order of SWV was 1665 trees $/ \mathrm{hm}^{2}$ $>2490$ trees $/ \mathrm{hm}^{2}>1110$ trees $/ \mathrm{hm}^{2}>832$ trees $/ \mathrm{hm}^{2}>624$ trees $/ \mathrm{hm}^{2}>499$ trees $/ \mathrm{hm}^{2}>$ 416 trees $/ \mathrm{hm}^{2}$, and the SWV at 1665 trees $/ \mathrm{hm}^{2}$ was significantly increased by $156.86 \%$ compared with that at 416 trees $/ \mathrm{hm}^{2}$. SV and SWV displayed high phenotypic variation (coefficient of variation (CV) 17.39-38.63\%), much higher than $\mathrm{DBH}$ and $\mathrm{H}$ variations.

Joint variance analyses of all studied growth traits of triploid hybrid clones are shown in Table 3. The initial planting density significantly affected the DBH, H, SV, and SWV of 11-year-old triploid hybrid clones. The effects of the initial planting density on the growth traits of 11-year-old triploid Chinese white poplar are further compared in Figure 1. The DBH of trees planted at 416 trees $/ \mathrm{hm}^{2}$ was significantly higher than that of trees planted at 832 trees $/ \mathrm{hm}^{2}, 1100$ trees $/ \mathrm{hm}^{2}, 1665$ trees $/ \mathrm{hm}^{2}$, and 2490 trees $/ \mathrm{hm}^{2}$ (Figure 1a). The $\mathrm{H}$ of trees planted at 416 trees $/ \mathrm{hm}^{2}$ was significantly higher than that of trees planted at 1100 trees $/ \mathrm{hm}^{2}, 1665$ trees $/ \mathrm{hm}^{2}$, and 2490 trees $/ \mathrm{hm}^{2}$ (Figure $1 \mathrm{~b}$ ). The SV of trees planted at 416 trees $/ \mathrm{hm}^{2}$ was significantly larger than that of trees planted at other densities except 499 trees $/ \mathrm{hm}^{2}$ (Figure 1c). The SWV of trees planted at 416 trees $/ \mathrm{hm}^{2}$ 
was significantly smaller than that of trees planted at 832 trees $/ \mathrm{hm}^{2}, 1110$ trees $/ \mathrm{hm}^{2}$, 1665 trees $/ \mathrm{hm}^{2}, 2490$ trees $/ \mathrm{hm}^{2}$. However, the difference among 416 trees $/ \mathrm{hm}^{2}$, 499 trees $/ \mathrm{hm}^{2}$, and 624 trees $/ \mathrm{hm}^{2}$ was not significant (Figure 1d). Therefore, low initial planting density is beneficial to the cultivation of a large diameter in triploid Chinese white poplar.

Table 2. Clone mean $( \pm \mathrm{SE})$, range of variation and coefficients of phenotypic variation $(\mathrm{CV} p \%)$ of growth traits, $\mathrm{BWD}$, and fiber properties at seven initial planting densities.

\begin{tabular}{|c|c|c|c|c|c|c|}
\hline \multirow{2}{*}{$\begin{array}{l}\text { Planting Density/ } \\
\quad\left(\text { trees } / \mathrm{Hm}^{2}\right)\end{array}$} & \multirow{2}{*}{ Traits } & \multicolumn{3}{|c|}{ Triploid Clones } & \multicolumn{2}{|c|}{ Diploid Clone (1316) } \\
\hline & & Mean \pm SE & Range & $\mathrm{CV} p \%$ & Mean \pm SE & Range \\
\hline \multirow{9}{*}{2490} & $\mathrm{DBH}(\mathrm{cm})$ & $15.30 \pm 2.04$ & $11.40-17.60$ & 13.32 & $11.87 \pm 1.85$ & $10.00-13.70$ \\
\hline & $\mathrm{H}(\mathrm{m})$ & $17.44 \pm 2.03$ & $13.20-20.00$ & 11.63 & $14.07 \pm 1.03$ & $13.20-15.20$ \\
\hline & $\mathrm{SV}\left(\mathrm{m}^{3}\right)$ & $0.1332 \pm 0.0424$ & $0.0569-0.1909$ & 31.81 & $0.0668 \pm 0.0243$ & $0.0438-0.0923$ \\
\hline & $\operatorname{SWV}\left(\mathrm{m}^{3} / \mathrm{hm}^{2}\right)$ & $331.6127 \pm 105.4758$ & $141.6810-475.3410$ & 31.81 & $166.3320 \pm 60.6227$ & $109.0620-229.8270$ \\
\hline & $\operatorname{BWD}\left(\mathrm{g} / \mathrm{cm}^{3}\right)$ & $0.348 \pm 0.017$ & $0.326-0.374$ & 5.01 & $0.364 \pm 0.017$ & $0.352-0.384$ \\
\hline & $\mathrm{FL}(\mathrm{mm})$ & $1.009 \pm 0.074$ & $0.880-1.085$ & 7.31 & $0.787 \pm 0.057$ & $0.740-0.850$ \\
\hline & FW $(\mu \mathrm{m})$ & $24.18 \pm 0.78$ & $23.40-26.00$ & 3.22 & $21.97 \pm 0.29$ & $21.80-22.30$ \\
\hline & FL/FW & $41.75 \pm 2.89$ & $36.51-45.38$ & 6.92 & $35.85 \pm 2.80$ & $33.32-38.85$ \\
\hline & $\mathrm{DBH}(\mathrm{cm})$ & $18.83 \pm 1.33$ & $16.50-20.80$ & 7.08 & $14.63 \pm 0.50$ & $14.10-15.10$ \\
\hline \multirow{6}{*}{1665} & $\mathrm{H}(\mathrm{m})$ & $20.38 \pm 1.13$ & $18.70-22.90$ & 5.53 & $16.87 \pm 0.91$ & $16.20-17.90$ \\
\hline & $\mathrm{SV}\left(\mathrm{m}^{3}\right)$ & $0.2237 \pm 0.0389$ & $0.1679-0.2980$ & 17.39 & $0.1148 \pm 0.0090$ & $0.1046-0.1216$ \\
\hline & $\operatorname{SWV}\left(\mathrm{m}^{3} / \mathrm{hm}^{2}\right)$ & $372.4605 \pm 64.7758$ & $279.5535-496.1700$ & 17.39 & $191.0865 \pm 14.9464$ & $174.1590-202.4640$ \\
\hline & $\operatorname{BWD}\left(\mathrm{g} / \mathrm{cm}^{3}\right)$ & $0.359 \pm 0.031$ & $0.313-0.421$ & 8.64 & $0.390 \pm 0.014$ & $0.379-0.406$ \\
\hline & $\mathrm{FL}(\mathrm{mm})$ & $1.080 \pm 0.049$ & $1.019-1.147$ & 4.51 & $0.827 \pm 0.012$ & $0.820-0.840$ \\
\hline & $\mathrm{FW}(\mu \mathrm{m})$ & $24.37 \pm 0.71$ & $23.50-25.70$ & 2.9 & $21.37 \pm 0.47$ & $21.00-21.90$ \\
\hline \multirow{10}{*}{1110} & $\mathrm{FL} / \mathrm{FW}$ & $44.36 \pm 2.11$ & $41.79-47.59$ & 4.76 & $38.84 \pm 0.31$ & $38.49-39.10$ \\
\hline & $\mathrm{DBH}(\mathrm{cm})$ & $18.43 \pm 3.13$ & $12.80-21.70$ & 16.97 & $17.23 \pm 2.06$ & $15.80-19.60$ \\
\hline & $\mathrm{H}(\mathrm{m})$ & $20.26 \pm 2.54$ & $14.70-22.50$ & 12.54 & $19.30 \pm 1.47$ & $17.70-20.60$ \\
\hline & $\mathrm{SV}\left(\left(\mathrm{m}^{3}\right)\right.$ & $0.2224 \pm 0.0816$ & $0.0784-0.3184$ & 36.70 & $0.1809 \pm 0.0544$ & $0.1392-0.2425$ \\
\hline & $\operatorname{SWV}\left(\mathrm{m}^{3} / \mathrm{hm}^{2}\right)$ & $246.8393 \pm 90.5864$ & $87.0240-353.4240$ & 36.70 & $200.8360 \pm 60.4185$ & $154.5120-269.1750$ \\
\hline & $\operatorname{BWD}\left(\mathrm{g} / \mathrm{cm}^{3}\right)$ & $0.355 \pm 0.026$ & $0.330-0.408$ & 7.41 & $0.380 \pm 0.033$ & $0.349-0.414$ \\
\hline & $\mathrm{FL}(\mathrm{mm})$ & $1.048 \pm 0.038$ & $0.967-1.086$ & 3.67 & $0.850 \pm 0.010$ & $0.840-0.860$ \\
\hline & FW ( $\mu \mathrm{m})$ & $23.93 \pm 0.62$ & $23.10-24.50$ & 2.58 & $21.70 \pm 0.53$ & $21.10-22.10$ \\
\hline & $\mathrm{FL} / \mathrm{FW}$ & $43.80 \pm 2.12$ & $40.12-46.58$ & 4.83 & $39.18 \pm 0.43$ & $38.77-39.62$ \\
\hline & $\mathrm{DBH}(\mathrm{cm})$ & $20.43 \pm 2.96$ & $13.90-23.40$ & 14.48 & $17.47 \pm 1.25$ & $16.20-18.70$ \\
\hline \multirow{6}{*}{832} & $\mathrm{H}(\mathrm{m})$ & $21.51 \pm 1.60$ & $17.80-23.10$ & 7.45 & $20.27 \pm 0.96$ & $19.40-21.30$ \\
\hline & $\mathrm{SV}\left(\left(\mathrm{m}^{3}\right)\right.$ & $0.2816 \pm 0.0822$ & $0.1083-0.3688$ & 29.19 & $0.1914 \pm 0.0346$ & $0.1578-0.2270$ \\
\hline & $\operatorname{SWV}\left(\mathrm{m}^{3} / \mathrm{hm}^{2}\right)$ & $234.3004 \pm 68.3838$ & $90.1056-306.8416$ & 29.19 & $159.2725 \pm 28.8209$ & $131.2896-188.8640$ \\
\hline & $\operatorname{BWD}\left(\mathrm{g} / \mathrm{cm}^{3}\right)$ & $0.345 \pm 0.020$ & $0.313-0.373$ & 5.77 & $0.379 \pm 0.015$ & $0.369-0.396$ \\
\hline & $\mathrm{FL}(\mathrm{mm})$ & $1.065 \pm 0.059$ & $0.988-1.165$ & 5.56 & $0.880 \pm 0.061$ & $0.810-0.920$ \\
\hline & FW $(\mu \mathrm{m})$ & $23.79 \pm 0.62$ & $22.80-24.50$ & 2.60 & $21.73 \pm 0.25$ & $21.50-22.00$ \\
\hline \multirow{10}{*}{624} & $\mathrm{FL} / \mathrm{FW}$ & $44.82 \pm 2.93$ & $41.17-49.30$ & 6.53 & $40.63 \pm 2.83$ & $37.47-42.93$ \\
\hline & $\mathrm{DBH}(\mathrm{cm})$ & $20.56 \pm 3.49$ & $14.80-25.00$ & 16.98 & $18.13 \pm 2.40$ & $15.70-20.50$ \\
\hline & $\mathrm{H}(\mathrm{m})$ & $21.20 \pm 2.50$ & $16.20-23.70$ & 11.81 & $20.30 \pm 2.23$ & $17.90-22.30$ \\
\hline & $\mathrm{SV}\left(\left(\mathrm{m}^{3}\right)\right.$ & $0.2871 \pm 0.1109$ & $0.1135-0.4410$ & 38.63 & $0.2106 \pm 0.0723$ & $0.1387-0.2832$ \\
\hline & $\operatorname{SWV}\left(\mathrm{m}^{3} / \mathrm{hm}^{2}\right)$ & $179.1504 \pm 69.2078$ & $70.8240-275.1840$ & 38.63 & $131.4352 \pm 45.0853$ & $86.5488-176.7168$ \\
\hline & $\operatorname{BWD}\left(\mathrm{g} / \mathrm{cm}^{3}\right)$ & $0.360 \pm 0.024$ & $0.325-0.387$ & 6.73 & $0.388 \pm 0.020$ & $0.371-0.410$ \\
\hline & $\mathrm{FL}(\mathrm{mm})$ & $1.075 \pm 0.059$ & $0.971-1.154$ & 5.47 & $0.850 \pm 0.036$ & $0.810-0.880$ \\
\hline & FW $(\mu \mathrm{m})$ & $24.08 \pm 0.74$ & $23.00-24.90$ & 3.09 & $21.60 \pm 0.26$ & $21.30-21.80$ \\
\hline & $\mathrm{FL} / \mathrm{FW}$ & $44.66 \pm 2.30$ & $40.29-47.11$ & 5.14 & $39.39 \pm 1.24$ & $38.12-40.60$ \\
\hline & $\mathrm{DBH}(\mathrm{cm})$ & $21.51 \pm 3.08$ & $15.40-24.50$ & 14.31 & $19.17 \pm 0.25$ & $18.90-19.40$ \\
\hline \multirow{6}{*}{499} & $\mathrm{H}(\mathrm{m})$ & $21.59 \pm 2.22$ & $17.70-23.80$ & 10.27 & $20.50 \pm 0.50$ & $20.00-21.00$ \\
\hline & $\mathrm{SV}\left(\mathrm{m}^{3}\right)$ & $0.3141 \pm 0.1018$ & $0.1322-0.4117$ & 32.41 & $0.2311 \pm 0.0107$ & $0.2201-0.2414$ \\
\hline & $\operatorname{SWV}\left(\mathrm{m}^{3} / \mathrm{hm}^{2}\right)$ & $156.7193 \pm 50.7935$ & $65.9678-205.4383$ & 32.41 & $115.3189 \pm 5.3230$ & $109.8299-120.4586$ \\
\hline & $\operatorname{BWD}\left(\mathrm{g} / \mathrm{cm}^{3}\right)$ & $0.359 \pm 0.033$ & $0.314-0.432$ & 9.21 & $0.403 \pm 0.045$ & $0.361-0.451$ \\
\hline & $\mathrm{FL}(\mathrm{mm})$ & $1.099 \pm 0.049$ & $1.041-1.186$ & 4.48 & $0.907 \pm 0.061$ & $0.840-0.960$ \\
\hline & $\mathrm{FW}(\mu \mathrm{m})$ & $24.08 \pm 0.66$ & $23.30-25.10$ & 2.72 & $21.90 \pm 0.96$ & $20.80-22.60$ \\
\hline \multirow{9}{*}{416} & FL/FW & $45.64 \pm 2.13$ & $42.66-49.83$ & 4.67 & $41.40 \pm 1.26$ & $40.19-42.70$ \\
\hline & $\mathrm{DBH}(\mathrm{cm})$ & $22.43 \pm 2.76$ & $16.80-25.60$ & 12.30 & $18.43 \pm 2.63$ & $15.40-20.10$ \\
\hline & $\mathrm{H}(\mathrm{m})$ & $22.43 \pm 1.39$ & $19.60-24.10$ & 6.22 & $20.00 \pm 2.03$ & $17.80-21.80$ \\
\hline & $\mathrm{SV}\left(\mathrm{m}^{3}\right)$ & $0.3486 \pm 0.0934$ & $0.1711-0.4705$ & 26.80 & $0.2150 \pm 0.0713$ & $0.1328-0.2593$ \\
\hline & $\operatorname{SWV}\left(\mathrm{m}^{3} / \mathrm{hm}^{2}\right)$ & $145.0037 \pm 38.8554$ & 71.1776-195.7280 & 26.80 & $89.4539 \pm 29.6549$ & $55.2448-107.8688$ \\
\hline & $\operatorname{BWD}\left(\mathrm{g} / \mathrm{cm}^{3}\right)$ & $0.359 \pm 0.042$ & $0.321-0.444$ & 11.75 & $0.380 \pm 0.012$ & $0.372-0.394$ \\
\hline & $\mathrm{FL}(\mathrm{mm})$ & $1.092 \pm 0.043$ & $1.030-1.141$ & 3.97 & $0.893 \pm 0.031$ & $0.860-0.920$ \\
\hline & FW $(\mu \mathrm{m})$ & $23.79 \pm 0.46$ & $22.90-24.50$ & 1.93 & $21.73 \pm 0.29$ & $21.40-21.90$ \\
\hline & $\mathrm{FL} / \mathrm{FW}$ & $45.93 \pm 2.01$ & $42.74-48.14$ & 4.38 & $41.04 \pm 0.89$ & $40.05-41.78$ \\
\hline
\end{tabular}

$\mathrm{H}=$ tree height, $\mathrm{DBH}=$ diameter at breast height, $\mathrm{SV}=$ stem volume, $\mathrm{SWV}=$ stand wood volume, $\mathrm{BWD}=$ basic wood density, FL = fiber length, FW = fiber width, FL/FW = fiber length/width. 
Table 3. Analyses of variance of growth traits, BWD, and fiber properties of 11-year-old triploid Chinese white poplar at seven planting densities combined.

\begin{tabular}{|c|c|c|c|c|c|c|}
\hline \multirow{2}{*}{ Traits } & \multicolumn{2}{|c|}{ Initial Planting Densities } & \multicolumn{2}{|c|}{ Clones } & \multicolumn{2}{|c|}{ Clones-Initial Planting Densities } \\
\hline & $\mathbf{F}$ & $p$ & $\mathbf{F}$ & $p$ & $\mathbf{F}$ & $p$ \\
\hline $\mathrm{DBH}$ & 13.975 & $<0.001$ & 32.214 & $<0.001$ & 1.121 & 0.371 \\
\hline $\mathrm{H}$ & 11.498 & $<0.001$ & 27.649 & $<0.001$ & 1.024 & 0.447 \\
\hline SV & 15.577 & $<0.001$ & 34.568 & $<0.001$ & 1.668 & 0.112 \\
\hline SWV & 24.863 & $<0.001$ & 27.075 & $<0.001$ & 1.097 & 0.389 \\
\hline BWD & 0.797 & 0.578 & 25.221 & $<0.001$ & 0.648 & 0.788 \\
\hline FL & 2.588 & 0.033 & 2.045 & 0.143 & 0.438 & 0.938 \\
\hline FW & 2.151 & 0.068 & 36.446 & $<0.001$ & 1.602 & 0.130 \\
\hline $\mathrm{FL} / \mathrm{FW}$ & 3.336 & 0.009 & 4.476 & 0.018 & 0.851 & 0.600 \\
\hline
\end{tabular}
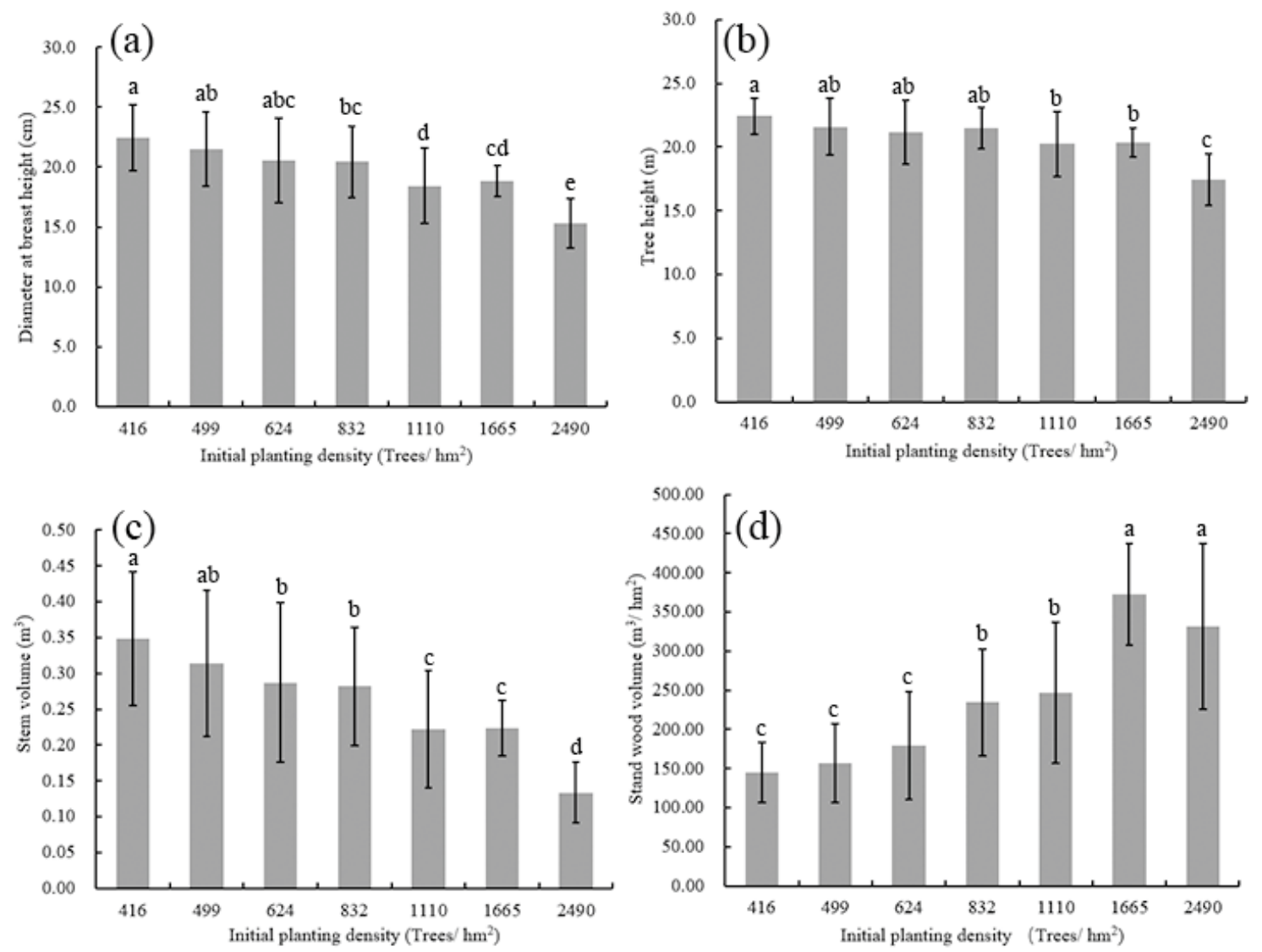

Figure 1. The effects of initial planting density on the growth traits of triploid Chinese white poplar: (a) The effects of initial planting density on the DBH. (b) The effects of initial planting density on the H. (c) The effects of initial planting density on the SV. (d) The effects of initial planting density on the SWV. Lowercase letters indicate significance at the $p<0.05$ level.

\subsection{Effect of Initial Planting Density on Basic Wood Density and Fiber Properties of Triploid Chinese White Poplar}

The mean values, range of variation, coefficients of the phenotypic variation of BWD, and fiber properties of the 11-year-old triploid hybrid clones within the seven initial planting densities are presented in Table 2. Among the seven initial planting densities, the BWD of triploid Chinese white poplar ranged from 0.345 to $0.360 \mathrm{~g} / \mathrm{cm}^{3}$, with an average of $0.355 \mathrm{~g} / \mathrm{cm}^{3}$. Additionally, the BWD of diploid clone 1316 ranged from 0.364 to $0.403 \mathrm{~g} / \mathrm{cm}^{3}$, with an average of $0.383 \mathrm{~g} / \mathrm{cm}^{3}$. Obviously, the BWD of triploid Chinese white poplar trees was slightly lower than that of trees from diploid clone 1316. In addition, triploid hybrid clones planted at a planting density of 624 trees $/ \mathrm{hm}^{2}$ had 
the largest BWD, and those planted at a density of 832 trees $/ \mathrm{hm}^{2}$ show the lowest BWD. The rank of BWD is 624 trees $/ \mathrm{hm}^{2}>416$ trees $/ \mathrm{hm}^{2}=499$ trees $/ \mathrm{hm}^{2}=1665$ trees $/ \mathrm{hm}^{2}>$ 1110 trees $/ \mathrm{hm}^{2}>2490$ trees $/ \mathrm{hm}^{2}>832$ trees $/ \mathrm{hm}^{2}$ (Table 2). As shown as Table 3, initial planting densities had no significant effects on BWD.

In Table 2, the fiber properties of triploid Chinese white poplar trees were longer than those of trees from diploid clone 1316 within the same planting density. Thus, the superior fiber properties of triploid hybrid clones make them become the preferred species in the pulp and paper industries. Triploid Chinese white poplar planted at 499 trees $/ \mathrm{hm}^{2}$ had the longest FL, and the shortest FL was observed at the planting density of 2490 trees $/ \mathrm{hm}^{2}$. Trees planted at 1665 trees $/ \mathrm{hm}^{2}$ had the largest FW, and the smallest FW was seen at planting densities of 416 trees $/ \mathrm{hm}^{2}$ and 832 trees $/ \mathrm{hm}^{2}$. The differences between FL and FW of the largest and smallest means were $8.92 \%$ and $2.44 \%$, respectively. The planting density of 416 trees $/ \mathrm{hm}^{2}$ showed the largest FL/FW, and the 2490 trees $/ \mathrm{hm}^{2}$ planting density showed the lowest ratio. The coefficient variation of fiber properties was smaller than that of growth traits, indicating that fiber properties were relatively stable. Joint variance analysis of fiber properties of triploid hybrid clones showed that initial planting density had a significant effect on FL and FL/FW (Table 3).

Multiple comparisons of the effects of the initial planting density on FL and FL/FW of triploid Chinese white poplar were conducted because initial planting density significantly affected FL and FL/FW (Figure 2). Multiple comparison results show that the FL of trees planted at the density of 2490 trees $/ \mathrm{hm}^{2}$ was significantly shorter than those planted at the density of $1665,624,499$, and 416 trees $/ \mathrm{hm}^{2}$ (Figure 2a). The FL/FW of trees grown at the density of 2490 trees $/ \mathrm{hm}^{2}$ was significantly smaller than those grown at the density of $1665,832,624,499$, and 416 trees $/ \mathrm{hm}^{2}$ (Figure $2 \mathrm{~b}$ ). The results showed that triploid poplar planted at high initial density was not suitable for the high-quality fiber industry due to the shorter FL and lower FL/FW.
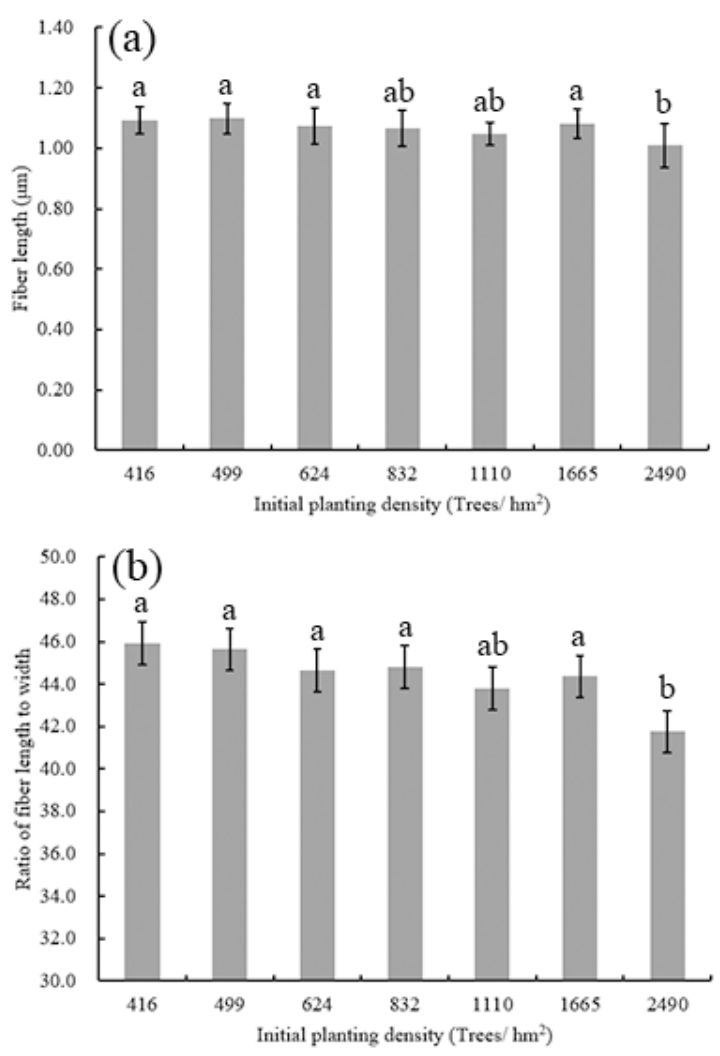

Figure 2. The effects of initial planting density on FL and FL/FW of triploid white poplar: (a) The effects of initial planting density on the FL. (b) The effects of initial planting density on the FL/FW. Lowercase letters indicate significance at the $p<0.05$ level. 


\subsection{Clonal Effect and Clones-Initial Planting Densities Interaction on Growth Traits and Wood} Properties of Triploid Chinese White Poplar

The results of the analysis of variance for the seven planting densities combined are summarized in Table 3. Significant differences in both growth traits and wood properties were found among the clones (except for FL). Clonal effects had greater effects on FW than planting density owing to its lower $P$ values. Multiple comparisons of the clonal effects on growth traits and wood properties displayed that triploid hybrid clones S86 and B301 were significantly taller than those of clones B331 in DBH, H, SV, and SWV (Figure 3a-d). Therefore, triploid Chinese white poplar S86 and B301, as preferred species, can improve yield of large diameter wood. The BWD and FW of triploid hybrid clone S86 were higher than those of clones B301 and B331 (Figure 3e,f). However, the FL/FW of clone B301 was larger than that of clone S86 and B331 (Figure 3g). In addition, individual tree levels for the tree growth and wood properties of 11-year-old triploid hybrid clones of Chinese white poplar within each initial planting density are presented in Table 4. Within all studied planting densities, clonal effects were significant for growth traits except for the initial densities of 832 and 1665 trees $/ \mathrm{hm}^{2}$. However, clonal effects were insignificant for all the studied wood properties except for the initial planting density of 1110 trees $/ \mathrm{hm}^{2}$. Therefore, it was necessary to select a suitable initial planting density to promote tree growth regardless of the clone.
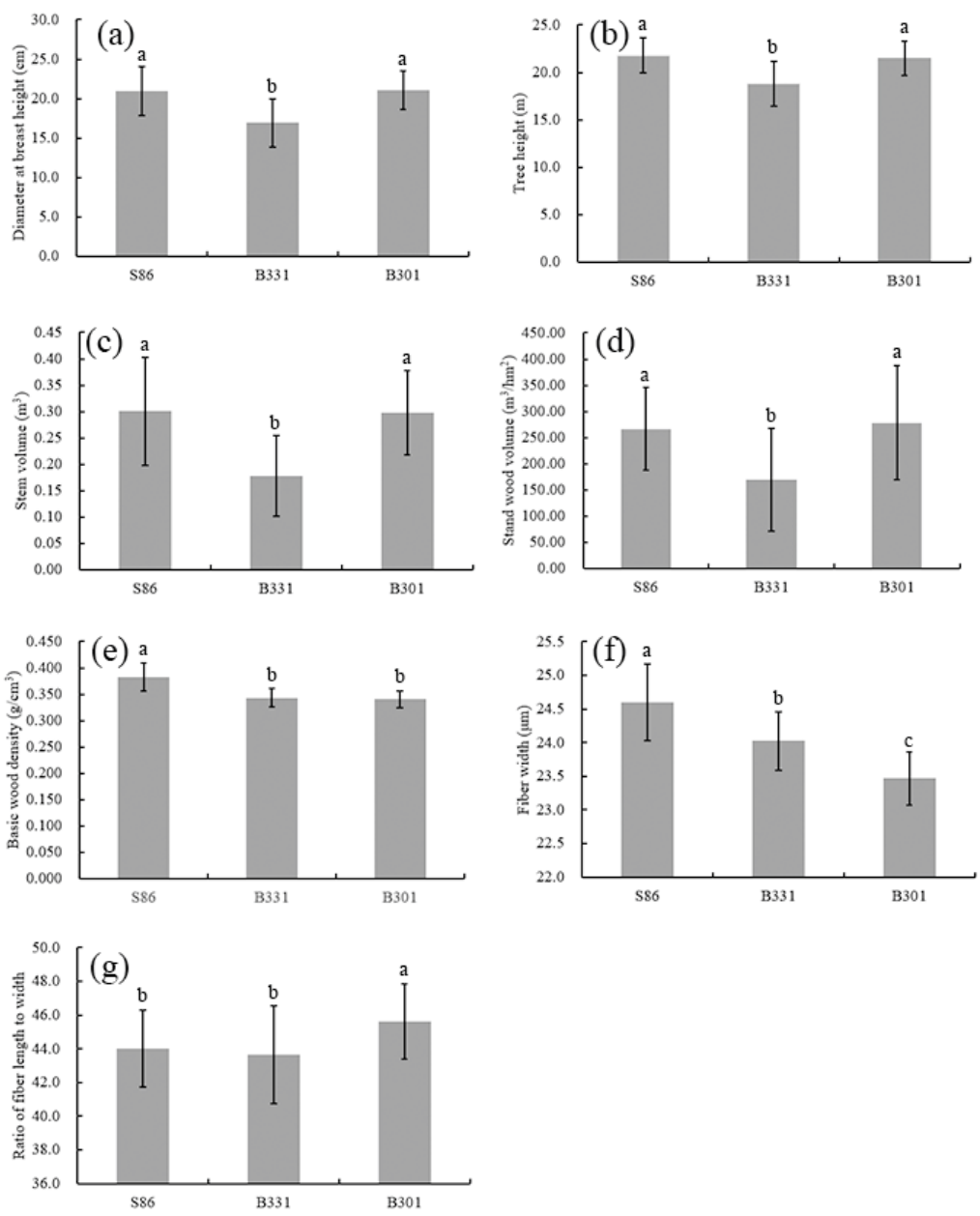

Figure 3. Clonal effects on growth traits and wood properties of triploid Chinese white poplar regardless of planting densities: (a) DBH of triploid Chinese white poplar. (b) H of triploid Chinese white poplar. (c) SV of triploid Chinese white poplar. (d) SWV of triploid Chinese white poplar. (e) BWD of triploid Chinese white poplar. (f) FW of triploid Chinese white poplar. (g) FL/FW of triploid Chinese white poplar. Lowercase letters indicate significance at the $p<0.05$ level. 
Table 4. Analysis of variance results for tree growth and wood properties of 11-year-old triploid Chinese white poplar plantation within each initial planting density.

\begin{tabular}{|c|c|c|c|c|c|c|c|c|}
\hline \multirow{2}{*}{$\begin{array}{l}\text { Planting Density } \\
\left(\text { trees } / \mathrm{Hm}^{2}\right)\end{array}$} & \multicolumn{8}{|c|}{$p$} \\
\hline & DBH & $\mathbf{H}$ & SV & SWV & BWD & FL & FW & FL/FW \\
\hline 2490 & 0.012 & 0.168 & 0.022 & 0.022 & 0.125 & 0.959 & 0.125 & 0.722 \\
\hline 1665 & 0.679 & 0.791 & 0.657 & 0.657 & 0.373 & 0.976 & 0.038 & 0.410 \\
\hline 1110 & 0.055 & 0.019 & 0.034 & 0.034 & 0.006 & 0.021 & $<0.001$ & 0.003 \\
\hline 832 & 0.162 & 0.158 & 0.139 & 0.139 & 0.021 & 0.699 & 0.139 & 0.637 \\
\hline 624 & 0.010 & 0.010 & 0.012 & 0.012 & 0.125 & 0.065 & $<0.001$ & 0.033 \\
\hline 499 & 0.016 & 0.048 & 0.008 & 0.008 & 0.169 & 0.888 & 0.011 & 0.700 \\
\hline 416 & 0.035 & 0.038 & 0.030 & 0.030 & 0.033 & 0.675 & 0.216 & 0.336 \\
\hline
\end{tabular}

No significant clones-initial planting densities interaction for growth traits, wood density, and fiber properties was found in this study (Table 3). Therefore, when the plantation rotation of triploid white poplar was longer than eleven years, the clones-initial planting densities interaction for tree growth and wood quality could be ignored.

\subsection{Phenotypic Correlations between Growth Traits, Basic Wood Density, and Fiber Properties within Planting Density}

The estimated phenotypic correlations between the growth traits, BWD, and fiber properties of the 11-year-old triploid Chinese white poplar plantation for each planting density are presented in Table 5. A weak and positive estimated correlation between BWD and growth traits within each planting density was seen. A positive or significantly positive estimated correlation was found between growth traits and FL and FL/FW within each planting density. The 2490,1665, and 499 trees $/ \mathrm{hm}^{2}$ planting densities showed a positive estimated correlation between growth traits and FW. However, a negative correlation between growth traits and FW was found at 1110, 832, 624, and 416 trees $/ \mathrm{hm}^{2}$ planting densities. Among the wood properties, a weak and positive estimated correlation between BWD and FL was observed, except for the 416 trees $/ \mathrm{hm}^{2}$ planting density. A significant positive estimated correlation between FL and FL/FW was seen. However, FW and FL/FW showed a negative estimated correlation. There were some strong positive autocorrelations among SV, SWV, $\mathrm{H}$, and $\mathrm{DBH}$, because SV and SWV derive from $\mathrm{H}$ and $\mathrm{DBH}$.

Table 5. Estimated phenotypic correlations between growth traits, wood basic density, and fiber properties of the three triploid hybrid clones at seven planting densities.

\begin{tabular}{|c|c|c|c|c|c|c|c|c|}
\hline $\begin{array}{l}\text { Planting Density } \\
\left(\text { trees } / \mathrm{Hm}^{2}\right)\end{array}$ & Trait & $\mathbf{H}$ & SV & SWV & BWD & FL & FW & FL/FW \\
\hline \multirow{8}{*}{2490} & $\mathrm{DBH}$ & $0.836^{* *}$ & $0.984^{* *}$ & $0.984^{* *}$ & 0.003 & 0.152 & 0.164 & 0.085 \\
\hline & $\mathrm{H}$ & & $0.891^{* *}$ & $0.891^{* *}$ & 0.149 & 0.199 & 0.128 & 0.157 \\
\hline & SV & & & $1.000^{* *}$ & 0.004 & 0.211 & 0.169 & 0.146 \\
\hline & SWV & & & & 0.004 & 0.211 & 0.169 & 0.146 \\
\hline & BWD & & & & & 0.503 & 0.586 & 0.265 \\
\hline & FL & & & & & & 0.370 & $0.896^{* *}$ \\
\hline & FW & & & & & & & -0.08 \\
\hline & FL/FW & & & & & & & \\
\hline \multirow{8}{*}{1665} & $\mathrm{DBH}$ & 0.627 & $0.969 * *$ & $0.969^{* *}$ & 0.318 & 0.732 * & 0.209 & 0.548 \\
\hline & $\mathrm{H}$ & & 0.796 * & 0.796 * & 0.497 & 0.329 & 0.352 & 0.094 \\
\hline & SV & & & $1.000^{* *}$ & 0.390 & 0.660 & 0.249 & 0.457 \\
\hline & SWV & & & & 0.390 & 0.660 & 0.249 & 0.457 \\
\hline & BWD & & & & & 0.098 & $0.808^{* *}$ & -0.385 \\
\hline & FL & & & & & & 0.219 & $0.821^{* *}$ \\
\hline & FW & & & & & & & -0.377 \\
\hline & FL/FW & & & & & & & \\
\hline
\end{tabular}


Table 5. Cont.

\begin{tabular}{|c|c|c|c|c|c|c|c|c|}
\hline $\begin{array}{l}\text { Planting Density } \\
\quad\left(\text { trees } / \mathrm{Hm}^{2}\right)\end{array}$ & Trait & $\mathbf{H}$ & SV & SWV & BWD & FL & FW & FL/FW \\
\hline \multirow{8}{*}{1110} & $\mathrm{DBH}$ & $0.919^{* *}$ & $0.992^{* *}$ & $0.992^{* *}$ & 0.105 & $0.898^{* *}$ & -0.309 & $0.843^{* *}$ \\
\hline & $\mathrm{H}$ & & $0.934^{* *}$ & $0.934^{* *}$ & 0.243 & $0.816^{* *}$ & -0.296 & 0.767 * \\
\hline & SV & & & $1.000^{* *}$ & 0.116 & $0.889^{* *}$ & -0.359 & 0.862 ** \\
\hline & SWV & & & & 0.116 & $0.889^{* *}$ & -0.359 & 0.862 ** \\
\hline & BWD & & & & & 0.232 & 0.639 & -0.182 \\
\hline & FL & & & & & & -0.166 & $0.849^{* *}$ \\
\hline & FW & & & & & & & -0.659 \\
\hline & FL/FW & & & & & & & \\
\hline \multirow{8}{*}{832} & $\mathrm{DBH}$ & $0.900 * *$ & $0.995^{* *}$ & $0.995^{* *}$ & 0.275 & 0.726 * & -0.416 & 0.785 * \\
\hline & $\mathrm{H}$ & & $0.909^{* *}$ & $0.909^{* *}$ & 0.505 & 0.612 & -0.309 & 0.652 \\
\hline & SV & & & $1.000^{* *}$ & 0.239 & $0.746^{*}$ & -0.444 & $0.815^{* *}$ \\
\hline & SWV & & & & 0.239 & $0.746^{*}$ & -0.444 & $0.815^{* *}$ \\
\hline & BWD & & & & & 0.067 & 0.494 & -0.139 \\
\hline & FL & & & & & & -0.161 & $0.916^{* *}$ \\
\hline & FW & & & & & & & -0.542 \\
\hline & FL/FW & & & & & & & \\
\hline \multirow{8}{*}{624} & $\mathrm{DBH}$ & $0.956^{* *}$ & $0.996^{* *}$ & $0.996^{* *}$ & 0.330 & $0.751 *$ & -0.187 & $0.902 * *$ \\
\hline & $\mathrm{H}$ & & $0.952^{* *}$ & $0.952 * *$ & 0.372 & $0.821^{* *}$ & -0.097 & $0.916^{* *}$ \\
\hline & SV & & & $1.000^{* *}$ & 0.363 & $0.747^{*}$ & -0.147 & $0.874^{* *}$ \\
\hline & SWV & & & & 0.363 & 0.747 * & -0.147 & $0.874^{* *}$ \\
\hline & BWD & & & & & 0.479 & 0.250 & 0.336 \\
\hline & FL & & & & & & 0.380 & $0.827^{* *}$ \\
\hline & FW & & & & & & & -0.203 \\
\hline & FL/FW & & & & & & & \\
\hline \multirow{8}{*}{499} & $\mathrm{DBH}$ & $0.859^{* *}$ & $0.987^{* *}$ & $0.987^{* *}$ & 0.612 & 0.443 & 0.372 & 0.186 \\
\hline & $\mathrm{H}$ & & $0.796^{*}$ & $0.796^{*}$ & 0.430 & $0.670 *$ & 0.394 & 0.399 \\
\hline & SV & & & $1.000^{* *}$ & 0.609 & 0.321 & 0.414 & 0.043 \\
\hline & SWV & & & & 0.609 & 0.321 & 0.414 & 0.043 \\
\hline & BWD & & & & & 0.038 & 0.301 & -0.149 \\
\hline & FL & & & & & & 0.241 & $0.819^{* *}$ \\
\hline & FW & & & & & & & -0.357 \\
\hline & $\mathrm{FL} / \mathrm{FW}$ & & & & & & & \\
\hline \multirow{8}{*}{416} & $\mathrm{DBH}$ & $0.943^{* *}$ & $0.994^{* *}$ & $0.994^{* *}$ & 0.425 & 0.197 & -0.453 & 0.354 \\
\hline & $\mathrm{H}$ & & $0.954^{* *}$ & $0.954^{* *}$ & 0.509 & 0.261 & -0.183 & 0.297 \\
\hline & SV & & & $1.000^{* *}$ & 0.505 & 0.161 & -0.422 & 0.307 \\
\hline & SWV & & & & 0.505 & 0.161 & -0.422 & 0.307 \\
\hline & BWD & & & & & -0.251 & -0.172 & -0.157 \\
\hline & FL & & & & & & -0.017 & $0.904^{* *}$ \\
\hline & FW & & & & & & & -0.439 \\
\hline & FL/FW & & & & & & & \\
\hline
\end{tabular}

${ }^{* *}$ significantly correlated at the 0.01 level, ${ }^{*}$ significant correlation at 0.05 level.

\section{Discussion}

Initial planting density determines the intensity of resource competition among individual trees [27]. At high plantation density, the intraspecific competition is fierce [28], and individual trees grow slowly or die $[3,29,30]$. Trees under low planting density may gain a greater allocation of ecological factors such as light, water and nutrients [31], thereby increasing the $\mathrm{DBH}, \mathrm{H}$, and SV of the trees. Thus, the growth status of trees differs under different initial planting densities. Several studies on the loblolly pine [32], oak [33,34], and poplar [12] also found that the average growth traits significantly increased with decreasing planting density. On the contrary, some studies showed that spacing has little or limited impact on average tree height growth [35-37].

In contrast, at the early stage of stand development, higher tree height was observed in higher planting density. For example, the $\mathrm{H}$ of radiata pine [38] at the ages of 3-5 years was greater in high planting densities than in a low planting density. This could be because 
increased competition results in more biomass allocated to tree elongation [39]. In this study, decreasing plantation densities greatly increased the $\mathrm{H}, \mathrm{DBH}$, and SV of 11-year-old triploid Chinese white poplar, following typical density effect results. The results are consistent with the study about the 9-year Chinese white poplar [22] plantation in North China Plain by Bo et al. As shown as Table 3, that initial planting density had a significant effect on SWV, which was consistent with the study about China fir [40]. Additionally, our study showed that the SWV decreased after an initial increase. The maximum SWV was found at the density of 1665 trees $/ \mathrm{hm}^{2}$. Perhaps due to light, water, and other environmental factors, there was no significant difference in the stand volume of poplars with a planting density of 2490 trees $/ \mathrm{hm}^{2}$ and 1665 trees $/ \mathrm{hm}^{2}$ (Figure 1d). Therefore, determining the suitable density of the triploid poplar plantation and adjusting it according to the dynamic change of stand growth process by thinning and rearing can ensure the full growth and development of stand individuals, maximize the use of limited stand space, and obtain the maximum benefit of stand.

According to density tests at home and abroad, whether BWD is affected by planting density is not completely consistent due to different tree species, site conditions, and afforestation density. Some studies on poplar [12], rubber tree [41,42], and teak [43] showed that the BWD has a negative relationship with the plantation density. In our study, no significant effect of initial planting density on the BWD was found, contrary to what had been previously reported [44,45]. Higher planting densities in poplar plantations achieve increased biomass with almost the same wood quality obtainable with lower densities based on our results. Contrasting results may be due to differences between species, environmental conditions, and the planting density tested [13]. For the fiber properties, the variation of FL within a planting density is controversial in woody species. Some studies have shown that FL was not affected by planting density in P. xiaohei [46] and rubber tree [42] because the FL development is strongly controlled by inheritance [47]. Instead, an increase in average values of the FL of the 38-year-old poplar [12] plantation with the decrease in plantation density was reported. In addition, the FL of the 5-year-old triploid Chinese white poplar [48] plantation decreased linearly with the trunk height. Thus, FL differences within planting densities might result from different genotypes, environmental factors, sample location in stem, and stand age. In the present study, planting density had significant effects on FL and FL/FW, suggesting that the fiber quality of triploid white poplar plantation could be improved by applying a suitable planting density.

According to joint variance analysis of all studied growth traits and wood properties (Table 3), the influence of initial planting density on growth traits is greater than that on wood properties, suggesting that the wood properties of triploid hybrid clones of Chinese white poplar were under stronger genetic control than growth traits. Our findings are consistent with the results described by Zhang et al. [26,49,50].

During the planting density experiment of white poplar, tree growth and wood properties were also affected by the clone used. Zhang et al. [17] reported that clonal effects significantly altered $\mathrm{H}$ and SWV of 3-year-old triploid Chinese white poplar. Subsequently, Zhang et al. $[18,19]$ also documented that clonal significantly affected the BWD, FL, and FW of 3-year-old triploid Chinese white poplar plantation. In this study, clonal effects were significant for all studied growth traits and wood properties except for FL, suggesting that both growth traits and wood properties were genetically controlled in triploid Chinese white poplar.

Some previous studies reported a positive correlation between FL and growth rate in Populus $[26,51,52]$. Thus, the FL of trees with higher growth rates was longer. A positive or significantly positive estimated correlation was found between growth traits and FL within each planting density in the present study. Therefore, it is crucial to select the ideal planting density to optimize productivity and wood quality.

The BWD findings contrasted with some former studies. For example, negative genetic correlations exist between the BWD and growth traits in Douglas fir [53] and poplar [12]. In this study, a weak and positive estimated correlation between BWD and 
growth traits within each planting density was found. Our findings conflict with the findings described by Zhang et al. [26] in a 5-year-old triploid Chinese white poplar plantation. These differences may be related to species, environmental conditions, and cambium ages of samples.

Additionally, there were some strong positive auto-correlations among SV, SWV, H and $\mathrm{DBH}$, because SV and SWV derived from $\mathrm{H}$ and $\mathrm{DBH}$. The results are similar to the research results on the Norway spruce [54] and poplar [12], which suggests that selecting suitable plantation density could be beneficial for improving growth traits.

\section{Conclusions}

To assess the effects of initial planting density on growth traits and wood properties, a total of 84 trees from 4 clones were sampled from an 11-year-old triploid Chinese white poplar plantation, including seven initial planting densities $(2490,1665,1110,832,624,499$, and 416 trees $/ \mathrm{hm}^{2}$ ). The initial planting density had a highly significant effect on growth traits $(p<0.001)$ and had a moderate effect on FL. Clonal effects were also significant $(p<0.05)$ for all studied traits except for FL. Clone S86 had a higher growth rate and the largest BWD and FW. Clones-initial planting densities showed no significant differences in growth traits and wood properties. A weak and positive estimated correlation between BWD and growth traits within each planting density existed. Our data support that an appropriate reduction in initial density in poplar plantations with a long rotation is a suitable strategy to promote tree growth and retain excellent wood processing characteristics. The results in this study were based on a small number of triploid clones, several initial planting densities, and a small amount of sampled tree for wood properties derived from a single site. Further research is needed to fully assess the effects of the initial planting density on growth traits and wood properties.

Author Contributions: Conceptualization, P.Z.; Formal analysis, Y.S.; Funding acquisition, P.Z.; Investigation, Y.S. and P.G.; Methodology, P.Z.; Software, Y.S.; Supervision, X.K.; Writing—original draft, Y.S. All authors have read and agreed to the published version of the manuscript.

Funding: This research was funded by the National Science Foundation of China (31570646).

Institutional Review Board Statement: Not applicable.

Informed Consent Statement: Not applicable.

Data Availability Statement: Data are contained within the article.

Acknowledgments: The authors would like to thank Fangdong Zhang from the Tianjin University of Science and Technology for his assistance with wood basic density and fiber properties measurement.

Conflicts of Interest: The authors declare no conflict of interest.

\section{References}

1. Puri, S.; Singh, V.; Bhushan, B.; Singh, S. Biomass production and distribution of roots in three stands of Populus deltoides. For. Ecol. Manag. 1994, 65, 135-147. [CrossRef]

2. Benomar, L.; DesRochers, A.; Larocque, G.R. The effects of spacing on growth, morphology and biomass production and allocation in two hybrid poplar clones growing in the boreal region of Canada. Trees 2012, 26, 939-949. [CrossRef]

3. Akers, M.K.; Kane, M.; Zhao, D.; Teskey, R.O.; Daniels, R.F. Effects of planting density and cultural intensity on stand and crown attributes of mid-rotation loblolly pine plantations. For. Ecol. Manag. 2013, 310, 468-475. [CrossRef]

4. Guler, C.; Şahin, H.I.; Aliogullari, S. Effect of spacing on some mechanical properties of narrow leaved ash (Fraxinus angustifolia) wood. Maderas. Cienc. Tecnol. 2015, 17, 773-788. [CrossRef]

5. Johnstone, W.D. The Effects of Initial Spacing and Rectangularity on the Early Growth of Hybrid Poplar. West. J. Appl. For. 2008, 23, 189-196. [CrossRef]

6. Truax, B.; Fortier, J.; Gagnon, D.; Lambert, F. Planting Density and Site Effects on Stem Dimensions, Stand Productivity, Biomass Partitioning, Carbon Stocks and Soil Nutrient Supply in Hybrid Poplar Plantations. Forests 2018, 9, 293. [CrossRef]

7. Liziniewicz, M.; Ekö, P.M.; Agestam, E. Effect of spacing on 23-year-old lodgepole pine (Pinus contorta Dougl. var. latifolia) in southern Sweden. Scand. J. For. Res. 2012, 27, 361-371. [CrossRef]

8. Fujimoto, T.; Koga, S. An application of mixed-effects model to evaluate the effects of initial spacing on radial variation in wood density in Japanese larch (Larix kaempferi). J. Wood Sci. 2010, 56, 7-14. [CrossRef] 
9. Lin, Y.; Yang, H.; Ivković, M.; Gapare, W.J.; Matheson, A.C.; Wu, H.X. Effect of genotype-by-spacing interaction on radiata pine wood density. Aust. For. 2014, 77, 203-211. [CrossRef]

10. Tun, T.N.; Guo, J.; Fang, S.; Tian, Y. Planting spacing affects canopy structure, biomass production and stem roundness in poplar plantations. Scand. J. For. Res. 2018, 33, 464-474. [CrossRef]

11. Erasmus, J.; Drew, D.M.; Wessels, C.B. The flexural lumber properties of Pinus patula Schiede ex Schltdl. \& Cham. improve with decreasing initial tree spacing. Ann. For. Sci. 2020, 77, 73. [CrossRef]

12. Ahmed, A.K.M.; Fu, Z.; Ding, C.; Jiang, L.; Han, X.; Yang, A.; Ma, Y.; Zhao, X. Growth and wood properties of a 38-year-old Populus simonii $\times$ P. nigra plantation established with different densities in semi-arid areas of northeastern China. J. For. Res. 2020, 31, 497-506. [CrossRef]

13. Melo, L.E.D.L.; Silva, C.D.J.; Protásio, T.D.P.; Mota, G.D.S.; Santos, I.S.; Urbinati, C.V.; Trugilho, P.F.; Mori, F.A. Planting density effect on some properties of Schizolobium parahyba wood. Maderas. Cienc. Tecnol. 2018, 20, 381-394. [CrossRef]

14. Zhu, Z.T. Genetic Improvement of Populus tomentosa; Chinese Forestry Press: Beijing, China, 2006.

15. Yang, S.; Lu, L.; Ni, Y. Cloned poplar as a new fiber resource for the Chinese pulp and paper industry. Pulp Paper Can. 2006, 107, 34-37.

16. Wang, L.B.; Zhang, Z.Y.; Kang, X.Y.; Song, L.J.; Shang, F.H. Effects of planting density on the early growth traits of white poplar hybrid clones. J. Beijing For. Univ. 2012, 34, 25-30. [CrossRef]

17. Zhang, P.D.; Kang, X.Y.; Zhao, G.R.; Meng, H.J. Relationship between growth and spacing of intensive short-rotation pulpwood stand of triploid Chinese white poplar. J. Northwest For. Univ. 2009, 24, 121-124.

18. Zhang, P.D.; Yao, S.; Kang, X.Y.; Pu, J.W. Timber yield and fiber morphology of intensive short-rotation pulpwood plantation for triploid hybrids of Populus tomentosa. Sci. Silv. Sin. 2011, 47, 121-126. [CrossRef]

19. Zhang, P.D.; Yao, S.; Kang, X.Y.; Pu, J.W. Wood basic density and chemical components in intensive short-rotation pulpwood plantation for triploid hybrids of Populus tomentosa. Sci. Silv. Sin. 2011, 47, 133-138.

20. Xi, B.Y.; Wang, Y.; Jia, L.M.; Si, J.; Xiang, D.K. Property of root distribution of triploid Populus tomentosa and its relation to root water uptake under the wide-and-narrow row spacing scheme. Acta. Ecol. Sin. 2011, 31, 47-57.

21. Di, N.; Xi, B.; Jeremiah, R.P.; Wang, Y.; Li, G.-D.; Jia, L.-M. Root biomass distribution of triploid Populus tomentosa under wideand narrow-row spacing planting schemes and its responses to soil nutrients. Chin. J. Plant Ecol. 2013, 37, 961-971. [CrossRef]

22. Huijuan, B.; Jialei, Z.; Runzhe, Z.; Lishui, N.; Lianjun, S. Effects of planting density and clone type on growth and wood volume of Populus tomentosa stands. J. For. Res. 2020, 25, 444-449. [CrossRef]

23. Wang, Y.N.; Gao, X.L.; Suyalabayaer; Hai, L.; Li, Z.F.; Huang, S.R.; Zeng, Y.; Li, Z.H.; Wang, X.J. Effects of different densities and ages on growth of Larix principis—Rurechitii plantation in Daqing Mountains of Inner Mongolia. J. Inn. Mong. For. Sci. Tech. 2018, 44, 12-16. [CrossRef]

24. Chen, Z.S. The establishment of binomial stock volume tables of poplar. J. Foramin. Res. 1989, 2, 78-83. [CrossRef]

25. Smith, D.M. Maximum moisture content method for determining specific gravity of small wood samples. For. Pro. Lab. Rep. 1954, $12,2-4$.

26. Zhang, P.; Wu, F.; Kang, X. Genotypic variation in wood properties and growth traits of triploid hybrid clones of Populus tomentosa at three clonal trials. Tree Genet. Genomes 2012, 8, 1041-1050. [CrossRef]

27. Long, J.N.; Dean, T.J.; Roberts, S.D. Linkages between silviculture and ecology: Examination of several important conceptual models. For. Ecol. Manag. 2004, 200, 249-261. [CrossRef]

28. Boyden, S.; Binkley, D.; Stape, J.L. Competition among Eucalyptus trees depends on genetic variation and resource supply. Ecology 2008, 89, 2850-2859. [CrossRef]

29. Binkley, D.; Stape, J.L.; Bauerle, W.L.; Ryan, M.G. Explaining growth of individual trees: Light interception and efficiency of light use by Eucalyptus at four sites in Brazil. For. Ecol. Manag. 2009, 259, 1704-1713. [CrossRef]

30. Harrington, T.B.; Harrington, C.A.; DeBell, D.S. Effects of planting spacing and site quality on 25 -year growth and mortality relationships of Douglas-fir (Pseudotsuga menziesii var. menziesii). For. Ecol. Manag. 2009, 258, 18-25. [CrossRef]

31. Chen, S.X.; Yang, M.S.; Wang, L.P. Effect of spacing on volume, storm-resistance and wood quality of Eucalyptus urophylla. For. Res. 1990, 11, 435-438.

32. Zhao, D.; Kane, M.; Borders, B.E. Growth responses to planting density and management intensity in loblolly pine plantations in the southeastern USA Lower Coastal Plain. Ann. For. Sci. 2011, 68, 625-635. [CrossRef]

33. Ebrahimi, E.; Pourmajidian, M.R.; Jalilvand, H.; Fallah, A.; Waez-Mousavi, S.M. Effects of initial spacing on some allometric characteristics of 12-year-old Quercus castaneifolia plantation in central Mazandaran, Iranian Caspian forests. Caspian J. Environ. Sci. 2012, 10, 273-278.

34. Saha, S.; Kuehne, C.; Kohnle, U.; Brang, P.; Ehring, A.; Geisel, J.; Leder, B.; Muth, M.; Petersen, R.; Peter, J.; et al. Growth and quality of young oaks (Quercus robur and Quercus petraea) grown in cluster plantings in central Europe: A weighted meta-analysis. For. Ecol. Manag. 2012, 283, 106-118. [CrossRef]

35. Kuehne, C.; Kublin, E.; Pyttel, P.; Bauhus, J. Growth and form of Quercus robur and Fraxinus excelsior respond distinctly different to initial growing space: Results from 24-year-old Nelder experiments. J. For. Res. 2013, 24, 1-14. [CrossRef]

36. Andrzejczyk, T.; Liziniewicz, M.; Drozdowski, S. Effect of spacing on growth and quality parameters in a sessile oak (Quercus petraea) stands in central Poland: Results 7 years after planting. Scand. J. For. Res. 2015, 30, 710-718. [CrossRef] 
37. Hébert, F.; Krause, C.; Plourde, P.-Y.; Achim, A.; Prégent, G.; Ménétrier, J. Effect of Tree Spacing on Tree Level Volume Growth, Morphology, and Wood Properties in a 25-Year-Old Pinus banksiana Plantation in the Boreal Forest of Quebec. Forests 2016, 7, 276. [CrossRef]

38. Lin, Y.; Yang, H.; Ivković, M.; Gapare, W.J.; Matheson, A.C.; Wu, H.X. Effect of genotype by spacing interaction on radiata pine genetic parameters for height and diameter growth. For. Ecol. Manag. 2013, 304, 204-211. [CrossRef]

39. Uhl, E.; Biber, P.; Ulbricht, M.; Heym, M.; Horváth, T.; Lakatos, F.; Gál, J.; Steinacker, L.; Tonon, G.; Ventura, M.; et al. Analysing the effect of stand density and site conditions on structure and growth of oak species using Nelder trials along an environmental gradient: Experimental design, evaluation methods, and results. For. Ecosyst. 2015, 2, 17. [CrossRef]

40. Jia, Y.Y.; He, Z.M.; Zhou, L.L.; Ma, X.Q.; Wu, P.F.; Zhou, X.H.; Liu, Q.Q.; Liu, Y.H. Effects of planting densities on the growth and space utilization of young Cunninghamia lanceolata plantation. Chin. J. Ecol. 2016, 35, 1177-1181. [CrossRef]

41. Naji, H.R.; Sahri, M.H.; Nobuchi, T.; Bakar, E.S. Clonal and planting density effects on some properties of rubber wood (Hevea brasiliensis Muell. Arg.). Bioresources 2012, 7, 189-202.

42. Naji, H.R.; Bakar, E.S.; Soltani, M.; Ebadi, S.E.; Abdul-Hamid, H.; Javad, S.K.S.; Sahri, M.H. Effect of Initial Planting Density and Tree Features on Growth, Wood Density, and Anatomical Properties from a Hevea brasiliensis Trial Plantation. For. Prod. J. 2014, 64, 41-47. [CrossRef]

43. Roque, R.M.; Ledezma, V.A. Efecto del espaciamiento en plantación sobre dos propiedades físicas de madera de teca a lo largo del fuste. Madera Bosques 2003, 9, 15-27. [CrossRef]

44. Cassidy, M.; Palmer, G.; Smith, R.G.B. The effect of wide initial spacing on wood properties in plantation grown Eucalyptus pilularis. New For. 2013, 44, 919-936. [CrossRef]

45. Downes, G.; Harwood, C.; Washusen, R.; Ebdon, N.; Evans, R.; White, D.; Dumbrell, I. Wood properties of Eucalyptus globulus at three sites in Western Australia: Effects of fertiliser and plantation stocking. Aust. For. 2014, 77, 179-188. [CrossRef]

46. Jiang, Z.-H.; Wang, X.-Q.; Fei, B.-H.; Ren, H.-Q.; Liu, X.-E. Effect of stand and tree attributes on growth and wood quality characteristics from a spacing trial with Populus xiaohei. Ann. For. Sci. 2007, 64, 807-814. [CrossRef]

47. Zobel, B.J.; van Buijtenen, J.P. Wood Variation: Its Causes and Control; Springer: Berlin, Germany, 1989; p. 363. [CrossRef]

48. Wu, F.; Zhang, P.; Pei, J.; Kang, X. Within-stem variation in wood properties of triploid hybrids of Populus tomentosa at three clonal trials. Scand. J. For. Res. 2014, 29, 71-76. [CrossRef]

49. Zhang, P.; Wu, F.; Kang, X. Genetic control of fiber properties and growth in triploid hybrid clones of Populus tomentosa. Scand. J. For. Res. 2013, 28, 621-630. [CrossRef]

50. Wu, F.; Zhang, P.; Pei, J.; Kang, X. Genotypic parameters of wood density and fiber traits in triploid hybrid clones of Populus tomentosa at five clonal trials. Ann. For. Sci. 2013, 70, 751-759. [CrossRef]

51. Holt, D.H.; Murphey, W.K. Properties of hybrid poplar juvenile wood affected by silvicultural treatments. Wood Sci. 1978, 10, 198-203.

52. Lei, H.; Gartner, B.L.; Milota, M.R. Effect of growth rate on the anatomy, specific gravity, and bending properties of wood from 7-year-old red alder (Alnus rubra). Can. J. For. Res. 1997, 27, 80-85. [CrossRef]

53. Johnson, G.R.; Gartner, B.L. Genetic variation in basic density and modulus of elasticity of coastal Douglas-fir. Tree Genet. Genomes 2006, 3, 25-33. [CrossRef]

54. Gerendiain, A.Z.; Peltola, H.; Pulkkinen, P.; Ikonen, V.-P.; Jaatinen, R. Differences in growth and wood properties between narrow and normal crowned types of Norway spruce grown at narrow spacing in Southern Finland. Silva Fenn. 2008, 42, $423-437$. [CrossRef] 